\title{
Geografia da violência no campo brasileiro: 0 que dizem os dados de 2003
}

The Geography of Violence in the Brazilian Countryside: What the 2003 data tell us

Géographie de la violence dans la campagne brésilienne : ce que disent les données de 2003

\section{Carlos Walter Porto-Gonçalves}

\section{OpenEdition}

\section{Journals}

Edição electrónica

URL: http://journals.openedition.org/rccs/908

DOI: $10.4000 /$ rccs.908

ISSN: 2182-7435

\section{Editora}

Centro de Estudos Sociais da Universidade de Coimbra

\section{Edição impressa}

Data de publição: 1 outubro 2006

Paginação: 139-169

ISSN: 0254-1106

\section{Refêrencia eletrónica}

Carlos Walter Porto-Gonçalves, "Geografia da violência no campo brasileiro: O que dizem os dados de 2003 », Revista Crítica de Ciências Sociais [Online], 75 | 2006, posto online no dia 01 outubro 2012, consultado o 10 dezembro 2020. URL : http://journals.openedition.org/rccs/908 ; DOI : https:// doi.org/10.4000/rccs.908 


\section{CARLOS WALTER PORTO GONÇALVES}

\section{Geografia da violência no campo brasileiro: O que dizem os dados de 2003}

O artigo faz uma análise da violência no campo brasileiro, com base nos dados relativos à violência sobre as pessoas e às lutas sociais e de poder coligidos pela Comissão Pastoral da Terra - CPT. Partindo da construção de um conjunto de indicadores sobre a incidência e as formas, públicas e privadas, de violência exercida sobre as populações dos campos, centra a análise na geografia da violência e explora as simulitudes e as diferenças detectáveis entre regiões e estados do Brasil. A análise permite identificar o quanto os processos contemporâneos de desenvolvimento agrícola e de modernização sócio-económica do campo reproduzem, ou reinventam, relações sociais e de poder sustentadas na violência, que prolongam no tempo, em novos moldes, formas de moderno-colonialidade.

\section{Apresentação}

$\mathrm{O}$ artigo ${ }^{1}$ que o leitor ora tem em mãos tem as vicissitudes do campo em que foi gerado, qual seja, o de entidades de apoio a movimentos sociais que lutam pela invenção de direitos, no presente caso, na luta pela reforma agrária no Brasil. Trata-se de um estudo que me foi solicitado pela Comissão Pastoral da Terra - CPT, acredito, por minhas pesquisas sobre a geografia dos movimentos sociais, a que venho me dedicando no LEMTO Laboratório de Estudos de Movimentos Sociais e Territorialidades da Universidade Federal Fluminense. O estudo analisa os dados de violência contra a pessoa no campo brasileiro durante o ano de 2003, para publicação nos Cadernos que a CPT publica anualmente, desde 1985, sobre a violência contra os que lutam por justiça e reforma agrária no Brasil. Tais Cadernos da CPT destinam-se, sobretudo, aos seus agentes pastorais, muito embora no seu lançamento a CPT procure chamar a atenção da sociedade brasileira por meio de entrevistas coletivas à imprensa, diga-se de passagem, sem

\footnotetext{
${ }^{1}$ Colaboraram neste estudo o geógrafo-pesquisador Hugo Fioravante e a estagiária Andressa Lacerda, ambos do LEMTO-UFF. Nesta versão do estudo contemplo as finas observações do Conselho Editorial da Revista Crítica de Ciências Sociais, a quem agradeço pelas sugestões.
} 
muito êxito nesse aspecto. ${ }^{2}$ Não se trata, portanto, de um artigo científico convencional, muito embora o seja a carpintaria teórico-conceitual, metodológica e técnica que o sustenta.

O artigo vem tendo uma repercussão importante entre aqueles envolvidos com a questão por apontar para uma geografia da violência bem diferente da representação que os brasileiros geralmente fazem da sua geografia agrária. O estudo revelou que a violência não é um simples resquício associado ao velho latifúndio e a um mundo rural retrógrado, mas está claramente ligada ao agro-business e à modernização dos campos brasileiros - eis a tese central que saiu de nosso estudo.

Nesse sentido, devo confessar, o resultado surpreendeu até mesmo o autor deste artigo que, até então, partilhava daquela mesma crença, apesar de uma já larga experiência com a problemática. Foi somente a partir daí que despertei para o significado da modernização nas formações sociais periféricas, como a brasileira, associando o resultado deste estudo ao debate acerca da colonialidade do saber e do poder, tal como vêm formulando Edgardo Lander, Walter Mignolo, Catherine Walsh, Silvia Rivera Cusicanqui, Fernando Coronil, Enrique Dussel, Arturo Escobar e Aníbal Quijano, entre outros. A constituição do sistema-mundo iniciada em 1492, que confere pela primeira vez na história uma centralidade geopolítica à Europa, é, desde o início, marcada pela colonialidade. A América de colonização ibérica cumpre nessa configuração um papel protagônico e, a partir de então, não é mais o Oriente que serve de referência do caminho a se tomar ("se oriente, rapaz", já dissera o poeta Gilberto Gil).

Assim, estamos diante de um sistema-mundo moderno-colonial e não simplesmente de um sistema-mundo moderno. Ainda está para ser devidamente considerado na moderna história das técnicas o lugar das manufaturas de açúcar do Brasil, Cuba e Haiti nos séculos XVI e XVII, para não falar da tecnologia de mineração do ouro e da prata amplamente conhecida no interior do Tawantinsuyo, território onde habitavam os quéchua e os aimara entre outros, e do Anauac, onde habitam os maias, entre outros. A violência já ali estava modernizando o mundo. Aníbal Quijano nos alertou que o fim

\footnotetext{
${ }^{2} \mathrm{Na}$ coletiva à imprensa para divulgar os resultados das análises do ano de 2003 e que teve presença significativa de órgãos de imprensa nacionais, o Bispo Dom Tomás Balduíno, Coordenador Nacional da CPT, divulgou uma lista de pessoas ameaçadas de morte entre as quais constava o nome de Dorothy Stang. A lista não teve a menor repercussão na imprensa, o que não impediu que o tema viesse ocupar a imprensa um ano depois, exatamente quando do assassinato da freira estadunidense. Mais uma vez, e tal qual quando da morte de Chico Mendes, foi preciso uma enorme repercussão internacional para que a imprensa nacional repercutisse o fato. Assim, tudo indica que a imprensa nacional parece repercutir a repercussão internacional dessas mortes e não as mortes enquanto tais (Porto-Gonçalves, 2004).
} 
do colonialismo não significou o fim da colonialidade posto que, com a notável exceção tentada no Haiti, o estabelecimento de Estados nacionais independentes na América continuou marcado pela submissão dos povos originários e dos negros. A dupla emancipação tentada no Haiti sob o comando de Toussant de Louverture viu abater contra si todo o peso da colonialidade dos dois Estados que ensejaram duas das revoluções emblemáticas da modernidade, como os Estados Unidos e a França. ${ }^{3}$ A violência, vê-se, é constitutiva do sistema-mundo moderno-colonial nas suas diferentes configurações. ${ }^{4}$

A colonialidade do saber e do poder continua conformando nossos corações e mentes na medida em que os problemas que nos afligem são compreendidos por essa chave que nos conduz à idéia de que devem ser superados por mais modernização, olvidando-se que modernizar é colonizar. A modernização dos nossos cerrados e da Amazônia tem sido a atualização de práticas coloniais de regiões tomadas como atrasadas, subdesenvolvidas ou como vazios demográficos, ${ }^{5}$ enfim, por toda uma rede discursiva marcada pela colonialidade do saber. Nosso estudo sobre violência no campo brasileiro só nos causou surpresa pela atualidade dessa idéia, que as novas áreas de expansão agrícola no Brasil, sobretudo na região centro-oeste (Mato Grosso do Sul, Goiás, Mato Grosso) e na Amazônia meridional (na faixa que vai do Maranhão a Rondônia, passando pelo Pará e Tocantins), onde se encontram as mais modernas empresas do agro-business, vêm apresentando os maiores índices de violência no campo brasileiro.

\section{Identificando a violência}

Desde 1985 a Comissão Pastoral da Terra - CPT - vem coligindo dados sobre as lutas sociais e de poder no campo brasileiro. Trata-se da maior cobertura de dados sobre a violência no campo brasileiro que, pelo rigor com que são recolhidos, oferecem uma fonte inigualável para estudos sobre a evolução das lutas sociais no campo brasileiro. Nesse estudo levamos em consideração os dados recolhidos para o ano de 2003 sobre o número de

\footnotetext{
${ }^{3}$ A recente intervenção no Haiti teve entre seus principais protagonistas, mais uma vez, a França e os Estados Unidos, agora contando com a colaboração do Canadá e do Brasil.

${ }^{4}$ Assim como a hegemonia ibérica da primeira fase da constituição desse sistema-mundo marcou a cartografia com o meridiano de Tordesilhas, a hegemonia inglesa procurou imprimir seu meridiano próprio, o de Greenwich, para marcar a sua hegemonia. A memória desse caráter moderno-colonial do sistema-mundo pode ser vista muito recentemente nos Açores, quando ali se reuniram nada mais nada menos que os mandatários de Portugal, Espanha, Inglaterra e Estados Unidos para decidir a intervenção no oriente, na recente guerra contra o Iraque.

5 A idéia de vazio demográfico invisibiliza os habitantes dessas regiões e, se são regiões vazias de gente, não são povos e culturas a serem considerados e, assim, a ocupação é legítima. A idéia de vazio demográfico está a merecer uma análise mais cuidadosa.
} 
conflitos, de pessoas envolvidas em conflitos, de pessoas presas, de pessoas assassinadas, de famílias expulsas e de famílias despejadas, todos por unidades político-administrativas (estados).

O primeiro procedimento analítico que fizemos foi tentar identificar o significado de cada um desses números, contextualizando-os sócio-historicamente. Pelas razões que se seguem, agrupamos esses dados em três dimensões diferentes das lutas que se travam no campo brasileiro, a saber:

1) O grau de conflitividade e de envolvimento da sociedade brasileira no que concerne à evolução do seu quadro agrário;

2) o papel protagônico do poder público, em particular do poder judiciário e do poder executivo (aparelho policial), como parte desses conflitos;

3) o papel do poder privado no campo brasileiro, é dizer o papel do latifúndio (melhor seria dizer, do latifundiário).

Os dados coligidos pela CPT nos permitem formular uma análise com um elevado grau de precisão estatística para fenômenos com forte componente de indeterminação e acaso, como soem ser os que implicam as lutas sociais (cf. Porto-Gonçalves, 2001a). Vejamos um pouco mais de perto como podemos nos acercar dessa complexa questão.

A análise do grau de conflitividade foi apoiada no número de conflitos e no número de pessoas neles envolvidas. A contextualização histórica desde 1985 e a análise da sua diversidade na geografia brasileira nos mostram como a sociedade brasileira explicita suas contradições em torno, de um lado, da reprodução de um modelo agrário-agrícola fundado na extrema concentração de poder político, social e econômico latifúndiário ${ }^{6}$ e, de outro, aquele(a)s que lutam por uma reforma agrária como base necessária de uma sociedade mais justa. Nesse sentido, consideramos que o grau de conflitividade é a expressão concreta da significação da Reforma Agrária no contexto atual do desenvolvimento contraditório da sociedade brasileira. Afinal, se entendemos a questão agrária a partir do fato concreto de que o modelo agrário-agrícola está sendo posto em questão, o número de conflitos e de pessoas neles envolvidas é o melhor indicador da existência dessa questão. A Questão Agrária se mostra, assim, mais do que uma questão acadêmica. Afinal, enquanto houver segmentos sociais pondo em questão o modelo agrário-agrícola brasileiro haverá uma questão agrária. A análise

\footnotetext{
${ }^{6}$ A rigor, não existe distinção entre latifúndio produtivo e improdutivo. Afinal, todo latifúndio é produtivo, no sentido preciso que lhe atribuiria Michel Foucault, na medida que todo latifúndio produz uma determinada estrutura de relações sociais e de poder que, como o nome indica, é concentradora de poder. Assim, uma determinada estrutura de apropriação concentrada da terra não só nega a propriedade a muitos, mas afirma uma determinada forma social. Nesse exato sentido o latifúndio é produtivo de uma estrutura desigual de relações sociais e de poder (cf. Foucault, 1979).
} 
a seguir, acerca dos dados sobre o número de conflitos e de pessoas envolvidas nos conflitos, nos ajuda a compreender esses caminhos das lutas sociais no campo.

A análise do número de pessoas presas e de famílias despejadas se configura como um bom indicador do grau de violência do poder público. Aqui, o Estado atua tanto por meio do poder judiciário, que é quem exara as ordens de prisão e de despejo das famílias, como do poder executivo que por meio das polícias militar e civil executa (ou não) aquelas ordens.

O poder judiciário historicamente cumpre um papel central como parte das lutas sociais e de poder. Espinha dorsal na conformação do território, enquanto espaço apropriado e submetido a determinadas leis (onde uma certa lei impera) e, sobretudo, quanto ao direito de propriedade (e dos proprietários) da terra, o poder judiciário se constitui, na verdade, no eixo em torno do qual gira o Estado liberal, enquanto guardião da propriedade. Foram os juristas que conheciam o Direito Romano que foram convocados a constituir as Cartas Magnas em torno das quais haveriam de se organizar os primeiros Estados territoriais modernos. As rígidas formalidades do Estado português (e também do espanhol) faziam parte da necessidade de afirmar a propriedade pela precisa palavra dos letrados (Rama, 1985: 85) em terras cujas formas de apropriação pelas populações originárias não eram individuais ou privadas, nem sequer formalizadas. Dizia-se, até, que eram terras sem Rei e sem lei. É o jurista baiano Rui Barbosa quem nos diz: "Com que outra coisa, a não ser com as palavras, se haviam de fazer as leis? Vida, propriedade, honra, tudo quanto nos é mais precioso, dependerá sempre da seleção das palavras [...]. Um código civil terá de ser obra excepcional, monumento da cultura de sua época, [pois] mais que ser uma realização científica, é uma expressão da literatura nacional”. Angel Rama agrega que exatamente por isso "sua escritura devia ser rigorosa e, além disso, dissipar todos os equívocos possíveis. No caso dos códigos e das constituições, o rígido sistema semântico da cidade letrada encontrava justificação plena, pois resultava obrigatório que respondessem a um unívoco sistema interpretativo" (ibid.).

A análise do grau de violência do poder privado está apoiada nos dados sobre o número de pessoas assassinadas e de famílias expulsas. Embora os dados sobre pessoas assassinadas possam envolver casos em que o poder público está diretamente envolvido, como no caso de chacinas cometidas por policiais, como nos tristemente famosos massacres de Corumbiara e de Eldorado de Carajás, no ano de 2003 todos os 73 casos registrados de assassinatos não contaram com o concurso de policiais e, por isso, foram considerados como parte da violência do poder privado. No Brasil, para 
além das leis de terras que se fizeram desde as sesmarias até a de 1850, há um poder privado que atua aquém e além da mediação pública por meio de grilagens e violências várias, onde o Cartório, mais do que oferecer 'fé pública', faz parte dos recursos de poder a ser repartido entre os "amigos do rei", entre os fidalgos ( $f^{\prime} d^{\prime}$ 'algo, de filhos d'alguém), ainda hoje. Por mais que venha ganhando legitimidade, com o aprofundamento das lutas sociais e democráticas, o princípio que condiciona a propriedade à sua função social conforme o caput da Constituição Federal de 1988, ainda resiste a conservadora idéia de que o princípio da propriedade absoluta deve predominar.

A análise dos dados disponibilizados pelo Setor de Documentação da $\mathrm{CPT}$ nos indica como essa característica histórica se atualiza na unidade da diversidade que constitui a formação territorial brasileira hoje. O poder privado, encarnado na grande propriedade rural, tem sido o sustentáculo não só da manutenção como da re-produção das assimétricas relações sociais e de poder que conformam o campo brasileiro. A literatura sociológica, jurídica e historiográfica brasileira registra como uma das características mais significativas de nossa formação social, a indistinção entre o público e o privado (coronelismo, clientelismo, patrimonialismo, cartorialismo). Tanto Raimundo Faoro, como Sérgio Buarque de Holanda, Florestan Fernandes, Antonio Cândido, Marilena Chaú, Vitor Nunes Leal, entre outros, assinalam essa característica, embora o façam com ênfases diferenciadas. Assim, aquilo que deveria ser público entre nós tem um forte componente privado, de grupo e de parentesco. Ainda recentemente, quando dos escândalos envolvendo duas das maiores instituições nacionais de caráter regional (SUDAM e SUDENE) ${ }^{7}$, que ensejou o afastamento temporário de dois parlamentares - Srs. Jader Barbalho, do Pará, e Antônio Carlos Magalhães, da Bahia - foram seus parentes que assumiram seus mandatos na condição de suplentes.

Assim, com a concessão de terras aos que eram filhos de alguém ( $f^{\prime}$ d'algos), não só se os investia de uma prerrogativa de poder nas capitanias, que eram hereditárias, o que muito se tem assinalado, mas também se os investia do estatuto de capitães - daí capitania. As análises que valorizam a determinação econômica na formação social brasileira têm deixado escapar o profundo significado político da própria atividade econômica desde o período colonial, olvidando que o sucesso econômico era uma condição para a efetivação da conquista e, para isso, o proprietário que recebia uma sesmaria estava

\footnotetext{
7 Superintendência de Desenvolvimento da Amazônia e Superintendência de Desenvolvimento do Nordeste.
} 
investido de poderes políticos. O Código Civil de 1831, que instituiu a Guarda Nacional, reconfigura essa relação por meio do que viria a ser conhecido como coronelismo onde, mais uma vez, o poder privado foi investido de prerrogativas públicas (Leal, 1975). Tudo isso vai ensejar uma cultura política conformando as relações sociais e de poder, onde a lógica do favor se impõe sobre a lógica do direito, com uma cultura fortemente conduzida por uma lógica privatista, configurando um estado patrimonialista e cartorial (Faoro, 2000).

No Brasil, essa característica se fará sentir, embora de diferentes modos nas diferentes conjunturas, na permanente tensão entre centralismo e federalismo, que se mantém desde o período colonial, se torna aguda no Império e, por meio de diferentes pactos políticos desde a proclamação da República (Leal, 1975; Carvalho, 1999), chega até nós. É o que nos ensina a Política dos Governadores, que se seguiu à Proclamação da República, onde o poder das oligarquias latifundiárias regionais das antigas províncias imperiais recém convertidas em estados ${ }^{8}$ se reforça numa aliança que procura limitar o poder federal, naquele momento ocupado pelos militares que proclamaram a República; a Política do Café com Leite da República Velha; a nova lei de terras de 1892, que delega aos estados a prerrogativa de realizar o cadastro e todo o registro sobre as terras públicas e dar fé à propriedade privada, o que, na prática, significava entregá-las ao controle das oligarquias latifundiárias; a emergência do regionalismo nordestino, desde a década de 1910; a não extensão aos trabalhadores rurais da legislação trabalhista de Vargas, mostrando que o direito social não adentrava o "território do latifúndio"; a natureza autoritária da maior parte das Polícias Militares, sempre subordinadas ao poder executivo dos diferentes estados e, assim, sob forte influência das oligarquias regionais extremamente ciosas na defesa dessa prerrogativa de poder que, nos diferentes pactos políticos nacionais, sempre lhes é reservada. Veremos a seguir como a eleição de Luis Inácio Lula da Silva ensejou um aumento significativo da ação do poder público das unidades estaduais sobre os quais o governo federal não detém o controle direto.

Assim, em torno desses três eixos - Conflitividade, Violência do Poder Público e Violência do Poder Privado -, conduziremos nossa análise dos eventos de 2003.

\footnotetext{
${ }^{8}$ A mudança de nome de província para estado com a passagem da Monarquia à República é significativa dessa afirmação das oligarquias regionais.
} 


\section{Breves considerações metodológicas}

Além de analisarmos os dados da CPT quanto à sua evolução histórica, procedemos a uma cuidadosa análise para verificar a sua geograficidade. O lugar geográfico onde ocorre um fenômeno, ainda mais um fenômeno como um conflito social, não é indiferente, nem tampouco externo à sociedade, posto que os lugares geográficos são criações sociais. Acreditamos que a consideração das diferentes conjunturas experimentadas nas diferentes unidades da federação, enquanto unidade geograficamente delimitada e enquanto um container de poder, nos permite compreender a complexa unidade na diversidade da nossa formação social, que se manifesta mais apropriadamente quando analisada numa perspectiva territorial (geográfica). ${ }^{9}$ Para isso, lançamos mão da cartografia geográfica como instrumento de análise e linguagem que, acreditamos, amplia o diálogo e a compreensão da violência contra a pessoa. No tratamento específico dos dados, além da sua contextualização conceitual, como já indicamos acima, os consideramos não só em termos absolutos como, também, procuramos construir indicadores que nos permitam verificar tendências diferenciadas de processos sociais e políticos.

Para ilustrarmos a riqueza desse procedimento analítico baseado na elaboração de Índices de Intensidade, observemos que, embora o estado do Pará tenha registrado 33 assassinatos relacionados com a luta pela terra e demais conflitos agrários em 2003 (45,2\% do total nacional), esses dados indicam uma proporção menor de assassinatos do que o estado de Mato Grosso, onde ocorreram 9 assassinatos no mesmo ano (ou seja, 12,3\% do total). Isso se deve ao fato de o estado do Pará abrigar 6,5\% da população rural do país, enquanto o Mato Grosso abriga somente 1,6\%. Assim, obtivemos um Índice de Violência do Poder Privado (Assassinatos) para o estado do Pará de 6,95 (45,2 $\div 6,5)$, enquanto para o estado de Mato Grosso o mesmo procedimento acusa um índice de 7,69 $(13,3 \div 1,6)$.

Dada a importância que atribuímos ao uso desses índices, permita-nos o leitor um outro exemplo que, de certa forma, já vai nos introduzindo na metodologia que comandou nossa análise dos processos em curso.

O estado de Goiás registrou, em 2003, um número de 4.214 pessoas despejadas por meio de ação judicial. Isso corresponde a 9,9\% do total de pessoas despejadas no Brasil nesse ano. Considerando que Goiás abriga

\footnotetext{
9 A Constituição brasileira reconhece três níveis de unidades territoriais político-administrativa, a saber: (i) a União, constituída pelas instituições federais; (ii) os 27 estados e um Distrito Federal (a capital da República); e (iii) os mais de 5800 municípios. Registre-se que, pelas tradições histórico-políticas do país as oligarquias fundiárias mantêm um elevado grau de autonomia política nas unidades federadas estaduais. Como veremos adiante, à eleição de Luis Inácio Lula da Silva se seguiu um endurecimento político nas unidades federadas onde se faziam presentes governos dos partidos tradicionais (PFL) ou neoconservadores (PSDB).
} 
1,9\% da população rural brasileira, calculamos o índice que mede a Intensidade da Violência do Poder Público (Pessoas Despejadas) dividindo a porcentagem de Pessoas Despejadas em Goiás em 2003 (9,9\%) por 1,9\%, obtendo-se, assim, o índice de 5,21.

Esses indicadores nos permitem, na verdade, afirmar com precisão em que grau o poder público de cada estado está contribuindo com suas ações no contexto das lutas sociais e de poder, comparando essa proporção com a proporção da população rural de cada Unidade da Federação. Deste modo, se um estado tem uma porcentagem de pessoas despejadas por ações judiciais do total do Brasil de, digamos, $10 \%$, e tem a mesma proporção de população rural, assim também 10\%, seu índice será de 1,0. Todos os estados cujos indicadores estão abaixo de 1,0 é porque a porcentagem do evento sob análise (que pode ser o Número de Conflitos; ou o Número de Assassinatos; ou o Número de Famílias Despejadas por iniciativa das ações do poder judiciário) daquele estado no total nacional é inferior à porcentagem da população rural desse mesmo estado no total nacional. Quanto maior e acima de 1,0 for o índice de um determinado estado, mais intensa é a sua participação no fenômeno sob análise. Deste modo, podemos fazer com certa segurança afirmações acerca dos índices de violência contra as pessoas nas suas diferentes facetas.

Todos os indicadores foram devidamente cartografados e nos mapas que acompanham a estudo deixamos em branco todos os estados em que o evento sob análise registrou indicador abaixo de 1,0. Por exemplo, Minas Gerais registrou um total de $1,36 \%$ dos assassinatos ocorridos no campo brasileiro em 2003, enquanto sua participação na população rural é de 10,11\%, o que nos dá um Índice de Violência do Poder Privado (Assassinatos) de 0,13 . Nesse caso, por ser um índice menor que 1,0, o estado de Minas Gerais aparecerá em cor branca no mapa. Para os estados que obtiveram índices acima de 1,0, os categorizamos, sempre, em 3 faixas:

Alto - índices entre 1,0 e 2,0, ou seja, estados que participaram no evento sob análise com até duas vezes a sua participação na população rural do Brasil;

Muito Alto - índices entre 2,0 e 4,0;

Altíssimo - estados onde os índices foram mais do que o quádruplo de sua participação na população rural do país.

Assim, toda vez que adjetivarmos nossa análise falando em Alto, Muito Alto ou Altíssimo estamos ancorados em critérios estatísticos razoavelmente seguros (alguns dizem objetivos). Com isso combinamos uma análise quantitativa a uma qualitativa, superando dicotomias que tanto vêm caracterizando as análises sociológicas e geográficas. 
Diante do exposto acima, e para dar conta dos três eixos analíticos propostos, criámos os seguintes Indicadores:

Eixo 1 - Conflitividade:

- Índice de Conflitividade - com base no número de Conflitos de cada estado.

- Índice de Envolvimento da População em Conflitos - com base no número de Pessoas Envolvidas em Conflitos de cada estado.

Eixo 2 - Violência do Poder Público:

- Índice de Intensidade da Ação do Poder Judiciário 1: Pessoas Presas - com base no número de Prisões de cada estado.

- Índice de Intensidade da Ação do Poder Judiciário 2: Pessoas Despejadas - com base no número de Famílias Despejadas de cada estado.

Eixo 3 - Violência do Poder Privado

- Índice de Violência do Poder Privado 1: Assassinatos - com base no número de Assassinatos de cada estado.

- Índice de Violência do Poder Privado 2: Pessoas Expulsas - com base no número Pessoas Expulsas de cada estado.

Vejamos, agora, como cada um desses índices se mostrou no ano de 2003 nas diversas regiões e estados brasileiros, o que nos permite distinguir as diferentes feições com que se mostra a violência na problemática agráriaagrícola brasileira.

Primeira aproximação: contextualizando historicamente os dados de 2003 A CPT registrou no ano de 2003 o maior número de conflitos (1.490) e de famílias despejadas (34.453) no campo brasileiro desde que passou a acompanhar a violação dos direitos e a violência em 1985.

\section{QUADRO 1 - Violência contra a pessoa no campo}

Variação relativa (\%) 1999-2003

\begin{tabular}{|c|c|c|c|c|c|c|}
\hline & \multicolumn{2}{|c|}{ Conflitividade } & \multicolumn{2}{c|}{ Poder Público } & \multicolumn{2}{c|}{ Poder Privado } \\
\hline Anos & Conflitos & $\begin{array}{c}\text { Pessoas } \\
\text { Envolvidas }\end{array}$ & Presos & $\begin{array}{c}\text { Famílias } \\
\text { Despejadas }\end{array}$ & Assassinatos & $\begin{array}{c}\text { Famílias } \\
\text { Expulsas }\end{array}$ \\
\hline $1999-2000$ & $-31,9$ & $-20,7$ & $-40,2$ & $-25,4$ & $-22,2$ & $+203,0$ \\
\hline $2000-2001$ & $+31,5$ & $-24,0$ & $-30,4$ & $-16,0$ & $+38,0$ & $-82,4$ \\
\hline $2001-2002$ & $+05,1$ & $+04,3$ & $-37,8$ & $-27,8$ & $+48,3$ & $-4,1$ \\
\hline $2002-2003$ & $+61,0$ & $+106,0$ & $+140,5 \%$ & $+354,0$ & $+69,8$ & $+130,0$ \\
\hline
\end{tabular}

Fonte: Setor de Documentação da Secretaria Nacional da CPT

Elaboração: LEMTO - Laboratório de Estudos de Movimentos Sociais e Territorialidades - UFF 
Não bastassem esses dados, que se destacam como os maiores em toda a série histórica de 1985 a 2003, há que se considerar ainda que o ano de 2003 apresenta a peculiaridade de inversão de algumas tendências importantes:

1) a tendência de queda do número de prisões desde 1999 até 2002 (de 611 para 158) se inverte, passando a aumentar em 2003, com um registro de 380 casos (um aumento de $140,5 \%$ em relação ao ano anterior);

2) também se inverte a tendência de queda do número de famílias despejadas (de 21.468 em 1999 para 9.715 em 2002), saltando em 2003 para 34.453, seu máximo histórico até hoje (um aumento de 354\%);

3) o número de famílias expulsas, cuja queda vinha se delineando desde o ano 2000, voltou a crescer de modo expressivo em 2003 (+ 130\% em relação a 2002).

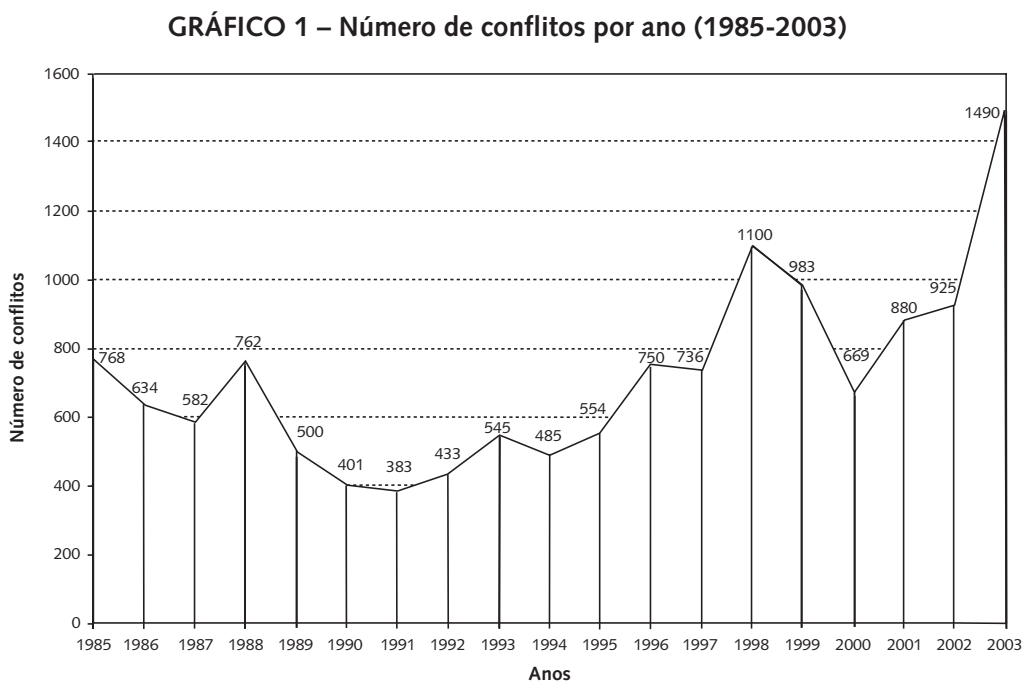

Assim se configura um quadro em 2003 em que o poder judiciário, quase sempre em ação conjunta com o poder executivo nas unidades político-administrativas da federação brasileira, passa a ter uma ação mais intensa, como se pode verificar pelos dados relativos ao número de prisões efetivadas e de pessoas despejadas. 
GRÁFICO 2 - Número de pessoas envolvidas em conflitos por ano (1985-2003)

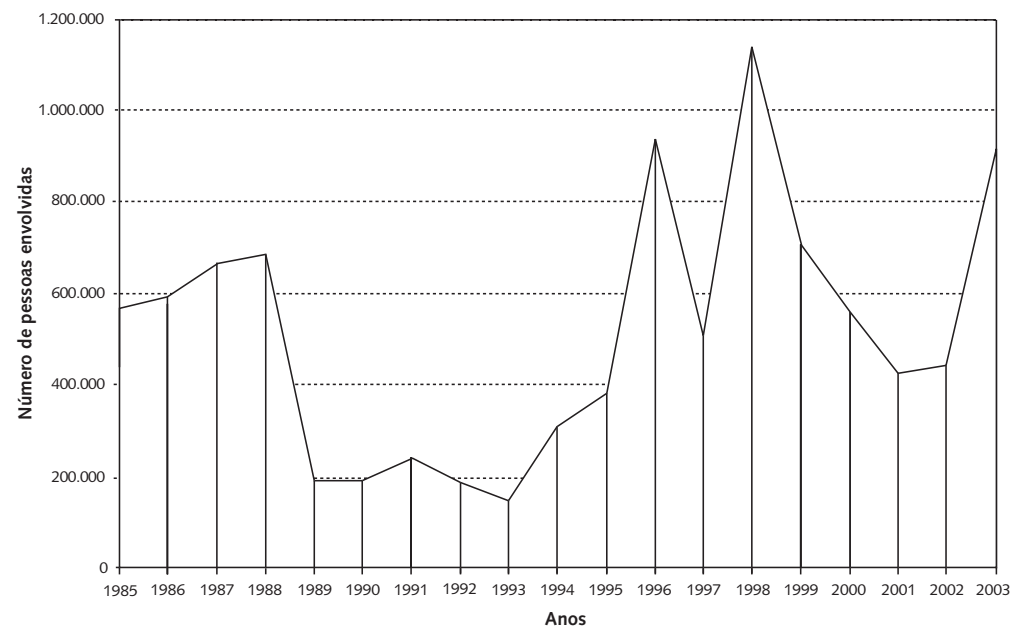

Observe-se que o número conflitos e de pessoas neles envolvidas, que já acusava pequeno crescimento em 2002, teve um aumento importante na sua taxa de crescimento. O número de conflitos saltou de um tímido crescimento de $5,1 \%$ de 2001 para 2002, para uma taxa de $62 \%$ de 2002 para 2003. Também o número de pessoas envolvidas em conflitos, que já invertera a tendência de queda em 2002 (ano eleitoral), aumentando 4,3\% em relação a 2001, saltou para uma taxa de crescimento de $106 \%$ entre 2002 e 2003 . O mesmo se observa, finalmente, quanto ao número de assassinatos, que salta de uma taxa de 39\% (2000-2001) e 48\% (2001-2002) para 69,8\% (2002-2003).

GRÁFICO 3 - Número de assassinatos por ano (1985-2003)

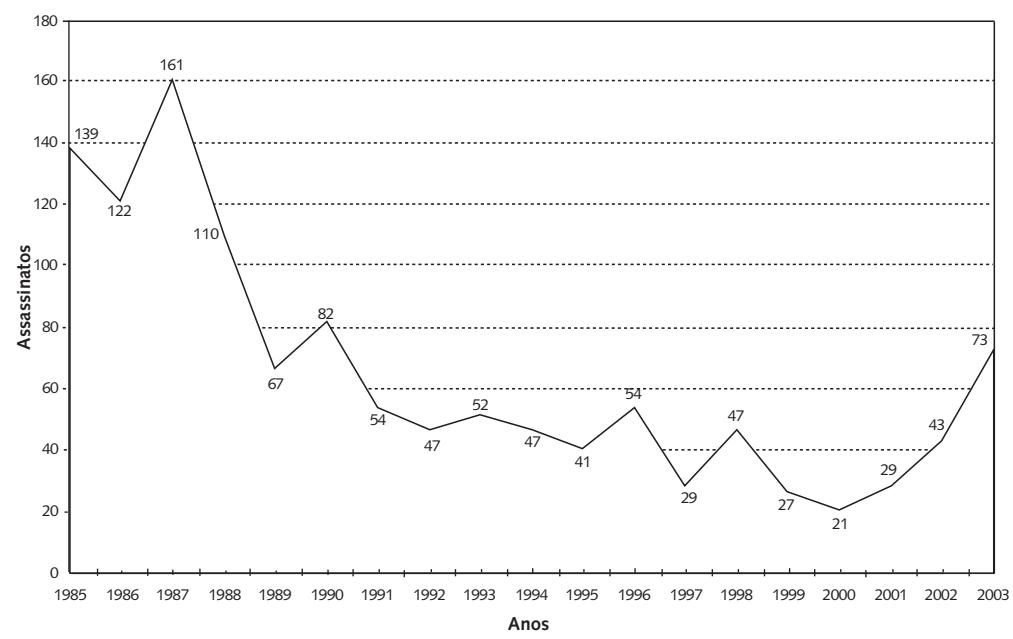


De um ponto de vista dos que lutam pela democratização no campo brasileiro (democratização do acesso à terra, das políticas públicas, inclusive a trabalhista, entre outras), o ano de 2003 mostrou uma intensificação da ação do poder judiciário em defesa da propriedade (e dos grandes proprietários), conforme indicam os números de ações de despejos e de prisões e, também, do poder privado, por meio de milícias e jagunços, conforme indicam os dados com aumento expressivo do número de expulsões e de assassinatos.

Podemos observar uma correlação direta entre o crescimento do número de conflitos e de assassinatos, o que indica que permanece uma das tendências históricas de resolução de conflitos no Brasil, a da violência direta sem mediação pública, por meio da ação de grupos privados, milícias e jagunços (cf. Alves, 1998) (ver cartografia da Violência Privada - Assassinatos, no Mapa 1 em Anexo).

Nesse sentido, chamamos a atenção para a tendência invertida no primeiro ano do governo Lula, quando houve um aumento da violência privada de $69,8 \%$ nos assassinatos e de $130 \%$ no de famílias expulsas, ao mesmo tempo que aumentou a ação do poder judiciário, sobretudo por meio do poder judiciário dos estados, com um aumento no número de presos de $140,5 \%$ e no de famílias despejadas de $354 \%$, porcentagem essa elevada, sobretudo se consideramos que o número de conflitos aumentara $62 \%$.

Esses dados indicam uma perigosa tendência que atenta contra a democracia e a justiça na sociedade brasileira, ao sinalizar para uma conjuntura de violência e arbítrio sempre que se configura um aumento de mobilização em busca da ampliação dos direitos sociais, conforme no imaginário popular indicam tanto o governo Lula como o período que se seguiu ao fim do regime ditatorial sob tutela militar ${ }^{10}$ e que culminou na Constituinte de 1988. Assim vem se manifestando a histórica matriz autoritária que subjaz às relações sociais e de poder no Brasil. Tudo indica que, assim como o fim do regime ditatorial sob tutela militar acentuou a violência privada (vide Gráfico 3 e

\footnotetext{
${ }^{10}$ Prefiro a expressão regime ditatorial sob tutela militar à já consagrada ditadura militar, porque essa última associa diretamente a ditadura aos militares. A primeira expressão tem a virtude de admitir que havia um regime ditatorial sob a tutela militar (1964-1985), mas não era essa tutela militar que caracteriza o caráter ditatorial e autoritário das relações sociais e de poder que, inclusive, extrapola esse período histórico específico. Talvez a olímpica sobrevivência ao fim do regime ditatorial de muitos políticos civis que apoiaram a tutela militar nos faça atentar para esse caráter autoritário que atravessa as relações sociais e de poder. Assim, não basta tirar o quepe do general para acabar com o autoritarismo e a ditadura. Caetano Veloso assustara a intelectualidade brasileira quando numa entrevista dissera que a ditadura era uma expressão autêntica da cultura política brasileira. Se considerarmos que não é a única expressão, não há como deixar de concordar com o poeta. A permanência da violência no campo, sobretudo contra os pobres por todo o lado, só reforça a constatação de Caetano Veloso.
} 
Mapa 1 em Anexo), a eleição e posse de Luiz Inácio Lula da Silva, independentemente do seu deslocamento da esquerda para o centro do espectro político, exacerbou a violência daqueles que, sobretudo no campo, vêm sistematicamente recusando a mediação pública dos conflitos ou instrumentalizando as instituições públicas para afirmar sua própria lei, como indica a regionalização (estadualização) por meio da ação do poder judiciário estadual, quase sempre acompanhado pela ação do poder executivo estadual.

A inversão de algumas tendências e a afirmação de outras nesse primeiro ano do governo Lula, conforme apontado acima, preocupa a todo(a) aquele(a) que luta por justiça e pela democracia, posto que os dados indicam um aumento desmesurado da ação do poder judiciário e a aceleração do índice de assassinatos no campo. Tudo isso aponta, perigosamente, para a conjuntura de finais dos anos 80 quando, enquanto a sociedade brasileira se redemocratizava e se mobilizava para estabelecer um novo pacto constitucional, a violência, sobretudo no campo, atingia seus maiores índices.

Eis, portanto, o desafio maior que todo(a)s haveremos de enfrentar na luta por justiça social e democracia, para o que, como se vê, a Reforma Agrária se mostra essencial: estabelecer um círculo virtuoso entre aumento de mobilização, aumento da justiça social e democracia, tomando como meta concreta e inegociável a diminuição da violência.

\section{O agrário posto em questão (1): envolvimento e conflitividade}

Como assinalamos na primeira parte desse estudo, houve um aumento tanto do Número de Conflitos, como de Pessoas Envolvidas em conflitos em 2003 (62\% e 106\%, respectivamente). Assim, podemos indicar que houve um aumento significativo do grau de conflitividade no campo brasileiro.

No Brasil, em 2003, 1 em cada 34 habitantes rurais esteve envolvido em conflitos. Esse índice, entretanto, era de 1 em cada 6 habitantes rurais envolvidos em conflitos na região Centro Oeste e de 1 para cada 28 na região Norte, as duas regiões que apresentavam Índice de Envolvimento da população maior que a média nacional. Para as demais regiões tivemos: na região Nordeste, 1 para 59 habitantes rurais; na região Sudeste, 1 para cada 84; e, na região Sul, 1 para cada 583.

Muito embora a região Nordeste seja a que apresentou a maior participação no total de conflitos $(32,2 \%)$, essa porcentagem é inferior à sua participação no total da população rural do país $(46,4 \%)$, o que nos dá um Índice de Conflitividade de 0,69 para essa região, comparável aos índices de conflitividade das regiões Sul $(0,7)$ e Sudeste $(0,66)$.

A região Centro Oeste é, de longe, a de maior conflitividade no país, com um Índice de Conflitividade de 3,8 e um Índice de Envolvimento da Popula- 
ção em Conflitos de 5,8, superiores em quase duas vezes ao Índice de Conflitividade da região Norte $(2,0)$ e mais de quatro vezes ao Índice de Envolvimento desta mesma região $(1,3)$. Assim sendo, a questão agrária brasileira vem se manifestando de modo particularmente agudo na região Centro Oeste, secundada pela região Norte.

Registre-se, entretanto, que o que essas regiões acusam de modo regionalizado é a gravidade da questão agrária nacional, visto a dinâmica sociogeográfica dessas regiões ser em grande parte impulsionada, nas últimas décadas, pela presença de empresários oriundos das regiões Sul e Sudeste (Paraná, Minas Gerais, São Paulo e Rio Grande do Sul), sobretudo no Centro Oeste e no Norte (estados de Rondônia, Tocantins e Pará), que entram em conflito: (i) com um campesinato remanescente ou originário da própria região que luta para permanecer na terra; (ii)com populações originárias (indígenas) que lutam pela demarcação de seus territórios; (iii) com os migrantes oriundos do Nordeste (Maranhão, Piauí, Ceará, Bahia, entre outros estados); e (iv) com migrantes de outras regiões do país, sobretudo do sul (Paraná, Santa, Catarina e Rio Grande do Sul) e do sudeste (Minas Gerais e Espírito Santo), que vêm se deslocando para essas áreas nas últimas décadas.

Mais adiante veremos que a violência é um componente estrutural das relações sociais e de poder, mesmo nos estados em que ocorrem os avanços considerados mais modernos no campo brasileiro, não podendo, portanto, ser associada ao atraso das relações no campo. Há uma espécie de neocoronelismo subjacente à expansão e re-produção das relações sociais e de poder, que se desenvolve no campo brasileiro. É uma lógica da violência que, ao se impor à revelia do Estado, traz gravíssimos danos à democracia e à justiça.

Somente duas regiões se destacam por apresentar uma porcentagem de conflitos e do número de pessoas envolvidas em conflitos acima da sua participação na população rural brasileira - as regiões Centro Oeste e Norte. São, assim, as duas regiões de maior conflitividade do país. Na região Centro Oeste a conflitividade atinge níveis estarrecedores, ultrapassando em muito a região Norte, como se pode ver tanto pelo seu Índice de Conflitividade como pelo Índice de Envolvimento da população em conflitos. No primeiro caso, seu Índice de Conflitividade é quase duas vezes maior que o da região Norte e, no caso do Grau de Envolvimento, chega a atingir quatro vezes e meia mais. São índices preocupantes, sobretudo quando se sabe que aí estão se desenvolvendo as mais modernas empresas do agro-business (ver Mapas 2 e 3 em Anexo).

Quando nos debruçamos na análise dos Índices de Conflitividade e de Envolvimento da População pelas diferentes unidades da federação, o que 
mais chama a atenção é que a região Centro Oeste é a única em que todos os estados que a compõem, inclusive o Distrito Federal, apresentam ambos os índices positivos, acusando uma verdadeira tensão social. Nos estados do Norte, Tocantins é o que mais se aproxima dos Índices de Conflitividade e de Envolvimento da região Centro Oeste, seguido pelos estados de Rondônia e Pará. Registre-se, ainda, o fato de o estado do Acre aparecer com um Índice de Conflitividade elevado $(1,4)$ embora, nesse estado, o número de pessoas envolvidas seja baixo, acusando um Grau de Envolvimento de 0,7.

O caso do Paraná também chama a atenção por ser o único estado da região Sul a apresentar índices Altos, tanto de Conflitividade como de Envolvimento da População (respectivamente 1,5 e 1,1). Destacam-se ainda, no Sudeste, os casos dos estados do Espírito Santo e de São Paulo que, embora tenham registrado um Grau de Conflitividade abaixo de 1 (Espírito Santo 0,3 e São Paulo 0,8), apresentaram um Índice de Envolvimento da população em conflitos Alto (Espírito Santo 1,4 e São Paulo 1,2).

Sinalize-se, finalmente, a região Nordeste, onde somente dois estados apresentaram Índices de Conflitividade e de Envolvimento da População acima de 1, a saber, Pernambuco e Sergipe. ${ }^{11}$ O Maranhão, que historicamente apresenta índices elevados, esteve abaixo de 1,0 com Índices de Conflitividade de 0,9 e de Envolvimento de Pessoas em Conflitos de 0,7.

Os dados nos autorizam a afirmar, portanto, que a questão agrária vem se mostrando mais aguda exatamente nas áreas onde vem se dando a expansão da moderna agricultura, como registram os estados de Mato Grosso, campeão absoluto nos índices analisados, acompanhado por Goiás, Mato Grosso do Sul, Distrito Federal e Tocantins, além de estados como o Paraná, São Paulo e Espírito Santo. Não devemos perder de vista, todavia, os fortes Índices de Conflitividade e de Envolvimento da população acusados nos estados de Pernambuco e Sergipe, embora sejam inferiores aos encontrados nas regiões Centro Oeste e Norte.

\section{O agrário posto em questão (2): a instrumentalização do poder judiciário e repressivo}

Os dados nos indicam como o poder judiciário, em maior ou menor grau associado ao poder executivo, tem tido um papel protagônico nas lutas sociais e de poder no campo brasileiro, sobretudo à escala das diferentes unidades federadas.

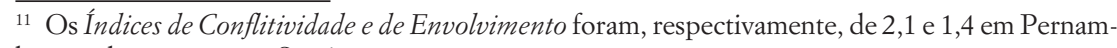
buco e de 1,2 e 3,1 em Sergipe. 
$\mathrm{Na}$ análise do número de Prisões efetivadas e do Número de Pessoas Despejadas por meio de ações judiciais chama-nos a atenção, logo de início, o fato de que somente duas regiões brasileiras atingem índices superiores a 1,0: novamente o Centro Oeste e o Norte. Cabe aqui destacar, sobretudo, os índices obtidos para a região Centro Oeste (4,9 e 7,6 respectivamente), que ultrapassam em muito os índices da região Norte (2,9 e 1,0 respectivamente), que é a segunda região em grau de intensidade da ação do poder público. Nessas duas regiões, o poder público vem tendo uma atuação muito mais intensa do que nas demais regiões, sendo que no Centro Oeste essa atuação tem registrado mesmo maior intensidade do que os Índices de Conflitividade e de Envolvimento de Pessoas em Conflitos, que vimos na seção anterior.

Em outras palavras, no Centro Oeste a intensidade da ação do poder público tem sido ainda maior que a conflitividade efetivamente existente. Para a região Norte, o mesmo se repete no que diz respeito ao Índice de Intensidade da Ação do Poder Público 1 - Pessoas Presas (2,9 contra um Grau de Conflitividade 2,0), muito embora não se reproduza o mesmo padrão com relação ao Índice de Intensidade da Ação do Poder Público 2 - Pessoas Despejadas (1,0, menor que o Grau de Envolvimento de Pessoas em Conflitos, de 1,3).

QUADRO 2 - Índices de intensidade da ação do poder público, por região (2003)

\begin{tabular}{|c|c|c|}
\hline \multirow{2}{*}{ Região } & \multicolumn{2}{|c|}{ Poder Público } \\
\cline { 2 - 3 } & $\begin{array}{c}1 \\
\text { Pessoas } \\
\text { Presas }\end{array}$ & $\begin{array}{c}2 \\
\text { Pessoas } \\
\text { Despejadas }\end{array}$ \\
\hline C. Oeste & 4,9 & 7,6 \\
\hline Nordeste & 0,4 & 0,6 \\
\hline Norte & 2,9 & 1,0 \\
\hline Sudeste & 0,8 & 0,7 \\
\hline Sul & 0,9 & 0,6 \\
\hline
\end{tabular}

Fonte: Setor de Documentação da CPT Nacional - 2003.

FIBGE - Censo Demográfico - 2000.

Elaboração LEMTO - Laboratório de Estudos de Movimentos Sociais e Territorialidades - UFF.

Quando observamos esses indicadores à escala das unidades federadas, vemos que o indicador geral para o Centro Oeste se reproduz em cada uma das suas unidades federadas, até mesmo para o Distrito Federal, sendo 
particularmente elevada a intensidade da atuação do poder público em Mato Grosso, onde chega a atingir os índices 6,6 e 10,1, respectivamente, para as duas modalidades de ação do poder público aqui analisadas (Pessoas Presas e Pessoas Despejadas). No primeiro desses índices (Prisões), o Mato Grosso se apresenta como o segundo estado mais alto do país, perdendo o primeiro lugar para Tocantins, e no segundo índice (Pessoas Despejadas) é o estado que apresenta o valor mais alto. Mato Grosso é o estado em que o poder público, sobretudo o poder judiciário, vem apresentando o seu maior grau de intensidade, se colocando num papel protagônico nas lutas sociais que ali se travam, sobretudo emitindo ordens de prisão contra famílias de sem-terra ou contra posseiros ou mesmo populações afrodescendentes (vide Quilombo Mata Cavalo), ou simplesmente exarando ordens de despejo. Observe-se que o fato dessas ordens de prisão e de despejo estarem sendo efetivadas em alto grau indica, também, uma forte relação da ação do poder judiciário junto com o poder executivo, na medida que os dados da CPT só registram o número de famílias e de prisões efetivadas e não de ordens de prisão ou de despejo exaradas pelo poder judiciário, mas não executadas pelo poder executivo (ver Mapas 4 e 5 em Anexo).

Todavia, chamamos a atenção para os índices alcançados pelos estados de Tocantins e Pará, onde o primeiro registrou o maior índice entre todos os estados do país para a Intensidade da Ação do Poder Público 1 - Pessoas Presas $(8,1)$, enquanto o Pará obteve o também Altíssimo grau de 4,2 para o mesmo indicador. Observe-se, entretanto, que nesses dois estados o poder judiciário não emitiu ordens de despejo com a mesma intensidade com que mandou prender lideranças de trabalhadores rurais. Em Rondônia, é o Índice de Ação do Poder Público 2 - Pessoas Despejadas que salta para 3,0 e, no Acre, atinge o elevado valor de 2,0. Em todos esses estados o Índice de Conflitividade é menor do que o Índice de Intensidade da Ação do Poder Judiciário, embora este seja ligeiramente inferior em alguns casos, como em Tocantins, onde é baixo o índice de Intensidade da Ação do Poder Público 2 - Pessoas Despejadas (0,4), o mesmo se verificando no Pará (0,9). Deste modo, não é a conflitividade que explica a ação mais intensa do poder público.

Merece destaque, ainda, o caso de São Paulo, em que em ambos os Índices de Intensidade de Ação do Poder Público 1 e 2 ultrapassam 1,0 (1,3 e 1,4 respectivamente). Também aí, o poder judiciário vem jogando um papel protagônico em defesa da propriedade (e dos proprietários), emitindo ordens de prisão e de despejos em grau proporcionalmente maior do que a participação da população rural do estado no total nacional. Registre-se, 
ainda, o estado do Paraná, onde o Índice de Intensidade da Ação do Poder Público 2 - Pessoas Despejadas é de 1,0.

$\mathrm{Na}$ quase totalidade desses estados em que o poder judiciário vem mantendo um índice elevado de ordens de prisão e de despejo, com a exceção do Acre, é onde temos a expansão da moderna agricultura empresarial, o chamado agronegócio (MT, GO, RO, MS, TO, PA), ou são estados onde o modelo agrário-agrícola moderno está consolidado, como São Paulo e Paraná. Nesse caso, merecem destaque os baixos índices dos estados de Santa Catarina e Rio Grande do Sul, onde é mais significativa a presença da pequena propriedade familiar.

Esse fato não nos deve deixar escapar os ainda elevados Índices de Intensidade da Ação do Poder Público em quatro estados do Nordeste que, sobretudo quanto ao número de famílias despejadas, estão acima de 1,0. O estado de Sergipe é o que, nesse caso, se destaca, com índice de 2,3. Os demais estados são o Rio Grande do Norte com 1,8; o Maranhão com 1,7; Pernambuco com 1,5. Sergipe e Alagoas destacam-se, ainda, pelo número de prisões, com 1,3 e 1,2 respectivamente. No caso de pessoas presas, o Maranhão apresenta índice de 0,97; Alagoas de 1,2; Pernambuco de 0,6; e o Rio Grande do Norte não acusa nenhum caso de pessoa presa em 2003. Assim, observase que, excetuando o caso Muito Alto de Sergipe para o Índice de Intensidade da Ação do Poder Público 2 - Pessoas Despejadas, os estados do Nordeste que acusam índices Altos relativamente à ação do poder público o fazem nas mesmas proporções que os estados de São Paulo e Paraná.

Também aqui verificamos que se reproduz, no Brasil, um modo de produção das relações sociais e de poder estruturado com e pela violência, mesmo no chamado setor moderno da sociedade, que, assim, convive com índices de estados situados em regiões tradicionais, como o Nordeste, que, embora apresentem índices elevados, são bastante inferiores aos dessas regiões de expansão de empresas capitalistas modernas.

Entretanto, observemos que poder público teve sua ação intensificada em 2003 à escala dos estados. Tudo indica que as oligarquias latifundiárias, perdendo o controle direto do poder executivo na esfera federal, pelo menos no início, quando estiveram fora do espectro de alianças do novo governo, tenham procurado instrumentalizar sua ação por meio do poder judiciário e, mesmo, do poder executivo estaduais, onde tradicionalmente exercem o poder de modo mais direto.

\section{O agrário posto em questão (3): a violência do poder privado}

Os dados que a CPT registrou para o ano de 2003 nos indicam ainda que, para além de lançarem mão da prerrogativa do que seria o monopólio da 
violência por meio do Estado, as relações sociais e de poder continuaram se constituindo com e pela violência privada. Vejamos, agora, como.

Indicámos na primeira parte desse estudo que, além do aumento das ordens de despejo e de prisões do poder judiciário, também se destaca nesse primeiro ano do governo Lula o aumento da violência privada, seja acentuando a taxa de crescimento dos assassinatos, seja invertendo a tendência de diminuição do número de pessoas expulsas da terra por ação direta de fazendeiros e suas milícias privadas, que vinha se verificando desde o ano 2000.

A região Norte é a que registra o maior número absoluto de pessoas assassinadas no país (61,6\% do total), o que lhe garante um Índice de Violência Privada Altíssimo $(5,0)$. Essa região é mais uma vez, juntamente com o Centro Oeste $(2,8)$, aquela onde os Índices de Violência superam 1,0 (ver Mapa 6 em Anexo).

Mais uma vez o estado do Mato Grosso se destaca por apresentar o maior índice de violência privada por estado de todo o país $(7,7)$, índice esse que é maior do que o da região Norte. Esses índices ainda permanecem elevados no Pará $(6,95)$, em Rondônia $(7,0)$ e Roraima $(5,6)$, todos Altíssimos, e Tocantins (2,9), onde é Muito Alto. O mais alto índice entre os estados do Nordeste fica por conta de Pernambuco $(1,8)$, que embora indique que esse estado está contribuindo para elevar a média nacional da violência privada, o faz num patamar inferior aos dos estados indicados.

Quanto à ação do poder privado por meio da expulsão de pessoas, a região Norte $(3,4)$ é a única em que os índices são maiores que 1,0 , tendo três entre os seis estados brasileiros que superam esse índice - Pará $(5,1)$, Rondônia $(3,3)$ e Tocantins $(1,7)$. Os restantes são dois estados do Nordeste (Paraíba, 4,2, e Pernambuco, 3,6) e um do sul (Paraná, 2,0). Chama-nos a atenção, ainda, a inexistência de registro de família expulsa pelo poder privado em Mato Grosso, estado que se destaca pelos índices elevados em geral. Talvez aqui caiba uma investigação mais apurada para tentar identificar até que ponto o fato do estado ser governado pelo maior proprietário produtor de soja do mundo e por um bloco de poder ligado ao agro-business estaria explicando esses elevados índices de violência do poder público e esse baixo índice de violência direta do poder privado por meio de expulsões de famílias de suas terras. A confirmar-se essa hipótese, estaríamos diante de um caso explícito de instrumentalização do poder público pelo poder privado (ver Mapa 7 em Anexo).

Mais uma vez, vê-se que aquilo que poderíamos caracterizar como ações típicas de um mandonismo coronelístico, que recusa a mediação pública de conflitos, está longe de se constituir como algo que esteja ancorado 
num passado histórico longínquo ou em regiões retrógradas. Ao contrário, está entre os estados onde se dá a expansão da moderna agricultura empresarial (neocoronelismo?). Assim, os dados o comprovam, a violência estrutura as relações sociais e de poder nas diferentes formas com que se reveste o desenvolvimento desigual e combinado do capitalismo no campo brasileiro.

\section{À guisa de reflexão (não) conclusiva: a colonialidade do poder}

Os dados acerca da violência contra a pessoa no campo brasileiro coligidos pelo Setor de Documentação da CPT indicam que o grau de conflitividade se acentuou no campo brasileiro em 2003, muito embora vários indicadores apontem que a tendência de crescimento do número de conflitos, de pessoas envolvidas e de assassinatos já viesse se desenhando desde o ano 2000. No caso desses indicadores, o que deve ser destacado é a exacerbação dessa tendência, o que é o mesmo que dizer aumento da tensão, ou seja, da intensidade de conflitos.

Cumpre destacar como específico nesse primeiro ano de governo Lula algo que, de certa forma, escapa ao próprio governo federal, qual seja o aumento espetacular, repito, da ação do poder público à escala dos estados, em conjunto com o poder executivo dos respectivos estados em maior ou menor grau e, ainda, um aumento expressivo da violência privada por meio da ação de milícias e jagunços. Os números chegam a atingir um verdadeiro estado de guerra em Mato Grosso, onde 6.455 famílias foram despejadas das terras que reivindicam. Se considerarmos uma média de 5 membros por cada família rural, isso nos remete ao número assombroso de 32.275 pessoas despejadas. Isso implica que, em apenas um ano, 6,2\% da população rural do estado foi, simplesmente, despejada. E despejada significa que houve uma ação formal do Estado nesse sentido, por meio da emissão de uma ordem de despejo seguida do seu cumprimento por órgãos repressivos. É, de fato, um verdadeiro estado de guerra.

Sublinhe-se, portanto, um deslocamento para a escala estadual do exercício do poder de modo mais intenso - eis uma questão central que os dados indicam.

Quando observamos os diferentes mapas vemos, ainda, como os estados em que está havendo a expansão da moderna agricultura empresarial são aqueles de maior conflitividade, maior violência privada e de ação do poder público, sobretudo do judiciário, muito embora a violência como prática estruturante das relações sociais e de poder também se faça sentir na região Nordeste, embora em níveis bem inferiores aos assinalados acima. 
QUADRO 3 - Ranking de Violência do Poder Público e do Poder Privado por Estado (2003) ${ }^{12}$

\begin{tabular}{|c|c|c|c|c|c|}
\hline \multirow{2}{*}{$\begin{array}{c}\text { Posição } \\
\text { no Ranking }\end{array}$} & \multirow[b]{2}{*}{ UF } & \multicolumn{2}{|c|}{ Poder Público } & \multirow{2}{*}{$\begin{array}{c}\text { Poder Privado } \\
\text { Assassinatos } \\
\text { C }\end{array}$} & \multirow{2}{*}{$\begin{array}{c}A+B+C \\
3\end{array}$} \\
\hline & & $\begin{array}{c}\text { Prisões } \\
\text { A }\end{array}$ & $\begin{array}{c}\text { Famílias Despejadas } \\
\text { B }\end{array}$ & & \\
\hline $1 .^{\circ}$ & MT & $2 .^{\circ}[07]$ & $1 .^{\circ}[12]$ & $1 .^{\circ}[07]$ & 8,7 \\
\hline $2 .^{\circ}$ & GO & $3 .^{\circ}[06]$ & $3 .^{\circ}[10]$ & - & 5,3 \\
\hline $3 .^{\circ}$ & $\mathrm{RO}$ & - & $5 .^{\circ}[08]$ & $2 .^{\circ}[06]$ & 4,7 \\
\hline $4 .^{\circ}$ & MS & $8 .^{\circ}[01]$ & $4 .^{\circ}[09]$ & $7 .^{\circ}[01]$ & 3,7 \\
\hline $5 .^{\circ}$ & TO & $1 .^{\circ}[08]$ & - & $5 .^{\circ}[03]$ & 3,7 \\
\hline $6 .^{\circ}$ & SE & $5 .^{\circ}[04]$ & $6 .^{\circ}[07]$ & - & 3,7 \\
\hline 7. ${ }^{\circ}$ & DF & - & $2 .^{\circ}[11]$ & - & 3,7 \\
\hline $8 .^{\circ}$ & $\mathrm{PA}$ & $4 .^{\circ}[05]$ & - & $3 .^{\circ}[05]$ & 3,3 \\
\hline 9. ${ }^{\circ}$ & $A C$ & - & $7 .^{\circ}[06]$ & - & 2,0 \\
\hline $10 .^{\circ}$ & $\mathrm{PE}$ & - & $10 .^{\circ}[03]$ & $6 .^{\circ}[02]$ & 1,7 \\
\hline $11 .^{\circ}$ & SP & $6 .^{\circ}[03]$ & $11 .^{\circ}[02]$ & - & 1,7 \\
\hline $12 .^{\circ}$ & $\mathrm{RN}$ & - & $8 .^{\circ}[05]$ & - & 1,7 \\
\hline $13 .^{\circ}$ & $\mathrm{RR}$ & - & - & $4 .^{\circ}[04]$ & 1,3 \\
\hline $14 .^{\circ}$ & $M A$ & - & 9. ${ }^{\circ}[04]$ & - & 1,3 \\
\hline $15 .^{\circ}$ & $\mathrm{AL}$ & $7 .^{\circ}[02]$ & - & - & 0,7 \\
\hline $16 .^{\circ}$ & PR & - & $12^{\circ}[01]$ & - & 0,3 \\
\hline
\end{tabular}

Fonte: Setor de Documentação da CPT.

Elaboração do LEMTO - Laboratório de Estudos de Movimentos Sociais e Territorialidades - UFF.

Isso nos remete à colonialidade do poder (e do saber) que comanda nossa formação social (Lander, 2000). O melhor indicador dessa colonialidade se faz sentir na própria idéia de modernização que, sempre, aparece justificando e legitimando a re-produção das relações sociais e de poder no Brasil. Talvez o melhor exemplo, hoje, seja a expansão do agronegócio, tanto na região Centro Oeste, como em Rondônia, ao longo da Cuiabá-Santarém,

\footnotetext{
${ }^{12}$ Só foram incluídos nesta tabela os estados que contribuíram acima de sua participação no total da população rural, ou seja, aqueles que apresentaram Índices de Intensidade acima de 1,0. Entre colchetes aparece a nota obtida pelo estado no índice em questão. Essa nota é igual à sua posição na ordem decrescente de todos os estados que foram considerados naquele índice, conforme o critério anterior. Por exemplo, o Paraná obteve a nota 1 no Índice de Intensidade do Poder Público Famílias Despejadas porque foi o $12 .^{\circ}$ nesse índice, enquanto o estado de Mato Grosso obteve nota 12 nesse mesmo índice por ter sido o $1 .^{\circ}$ em número de Ações do Poder Judiciário - Famílias Despejadas. Nesse caso a nota variou de 1 a 12 porque 12 estados obtiveram índices acima de 1 . Observe-se que, na coluna A, a maior nota foi 8, enquanto na Coluna $\mathrm{C}, 7$ foi a maior nota. Isto porque só 8 estados, na coluna $\mathrm{A}$, e 7 , na Coluna $\mathrm{B}$, registraram índices acima de 1,0.
} 
em Tocantins e no sul do Piauí (região de Uruçuaí), sul do Maranhão (região de Balsas) e oeste da Bahia (região de Barreiras). Como os dados indicam, a violência continua subjacente estruturando as relações sociais e de poder.

A tabela do ranking de estados mais violentos do Brasil no ano de 2003 nos mostra, simplesmente, que os 5 primeiros colocados - Mato Grosso, Goiás, Rondônia, Mato Grosso do Sul e Tocantins - são, todos, estados onde se expande a moderna agricultura empresarial.

Ora, o que talvez esses dados atualizem sejam as práticas que historicamente sempre fizeram do Brasil um território moderno, como já o eram os engenhos de cana de açúcar dos séculos XVI e XVII, os mais modernos que havia no mundo à época. Eles eram, assim, tão modernos como o são os elevados níveis de produtividade com pivôs centrais, sementes selecionadas, solos corrigidos e máquinas agrícolas computadorizadas que, hoje, fazem a moderna e violenta paisagem do Brasil Central e da Amazônia (Porto-Gonçalves, 2001b). Afinal, hoje se mata e desmata nos Cerrados e na Amazônia, do mesmo modo que, ontem, matou-se e desmatou-se na Mata Atlântica e nas Matas de Araucária, contra as populações originárias, quilombolas e camponeses de diversos matizes - seringueiros, ribeirinhos, retireiros (Araguaia), vazanteiros (São Francisco), geraizeiros, mulheres quebradeiras de coco babaçu, entre tantos.

O que, talvez, os dados sobre a violência contra a pessoa no campo venham nos ensinar é que a modernidade tem sido um poderoso meio de colonização e que, na verdade, é a moderno-colonialidade que vem caracterizando nossa formação social nos oferecendo mais do mesmo, sempre. Enfim, em nome da modernidade nos colonizam por meio da colonialidade do pensamento e da violência, prática com que se abre caminho para o (seu) progresso. É preciso ir além da modernidade colonial. Afinal, quantas vidas vêm sendo ceifadas em seu nome?

\section{Referências Bibliográficas}

Alves, José Cláudio de Souza (1998), Dos barões ao exterminio: uma história da violência na Baixada Fluminense. Tese de Doutorado. São Paulo: Departamento de Sociologia da USP.

Carvalho, José Murilo (1999), A construção da ordem. Rio de Janeiro: Relume Dumará e Edufrj.

Faoro, Raimundo (2000), Os donos do poder. São Paulo: Editora Globo.

Foucault, Michel (1979), A microfísica do poder. Rio de Janeiro: Ed. Graal.

Lander, Edgardo (org.) (2000), La colonialidad del saber: eurocentrismo y ciencias sociales - perspectivas latinoamericanas. Buenos Aires: Clacso. 
162 | Carlos Walter Porto Gonçalves

Leal, Vitor Nunes (1975), Coronelismo, enxada e voto. São Paulo: Editora Alfa-Ômega. Porto-Gonçalves, Carlos Walter (2001a), Geo-grafias: movimientos sociales, nuevas territorialidades e sustentabilidad. México: Ed. Siglo XXI.

Porto-Gonçalves, Carlos Walter (2001b), Amazônia, Amazônias. São Paulo: Ed. Contexto.

Porto-Gonçalves, Carlos Walter (2004), Geografando nos varadouros do mundo. Brasília: Ed. Ibama.

Rama, Angel (1985), A cidade das letras. São Paulo: Editora Brasiliense. 


\section{ANEXO}

\section{MINI ATLAS DA VIOLÊNCIA NO CAMPO - 2003}

\section{MAPA 1 - A Violência Privada - Assassinatos (2003)}

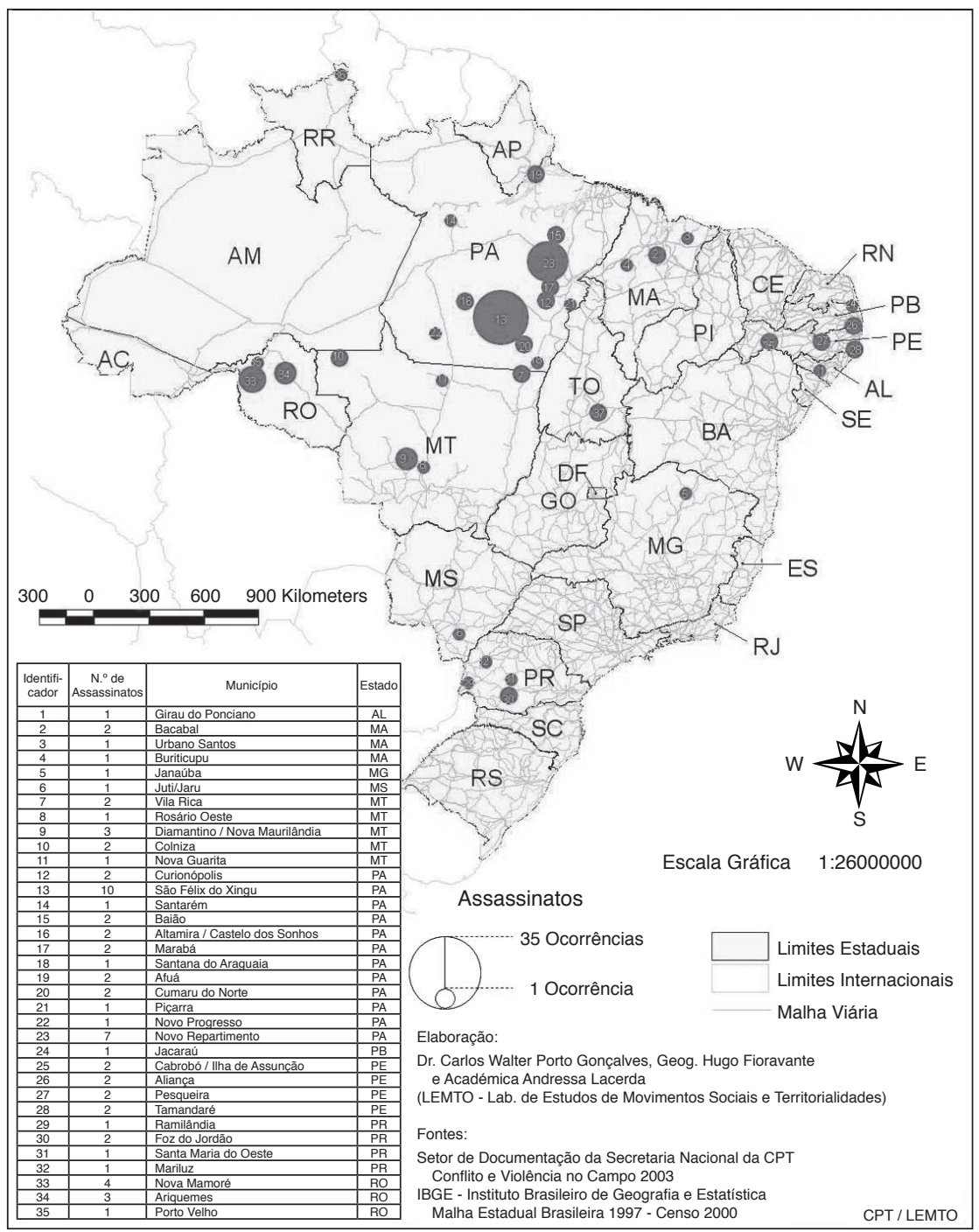


MAPA 2 - Índice de Conflitividade (2003)

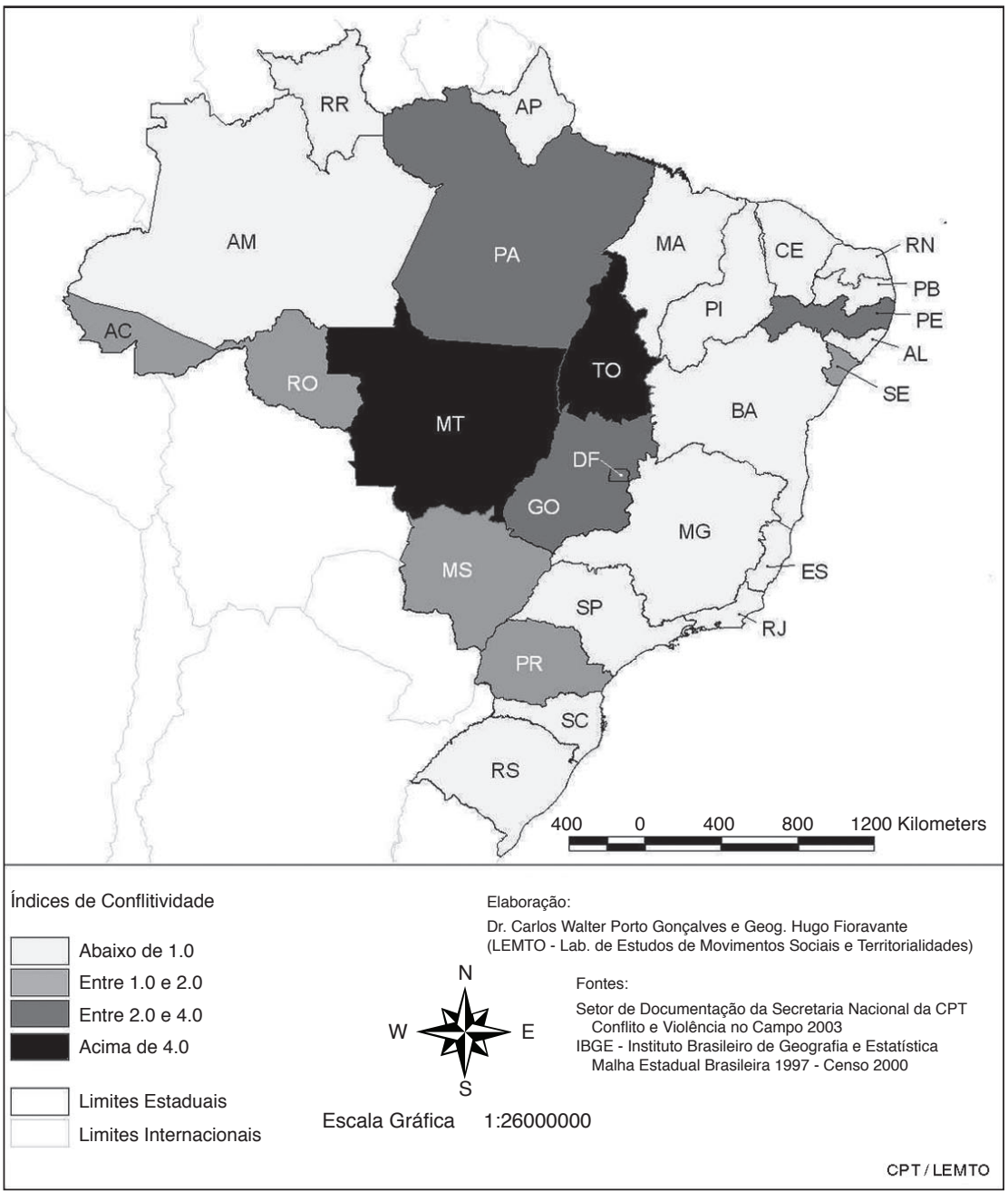


MAPA 3 - Índice de Envolvimento das Pessoas em Conflitos (2003)

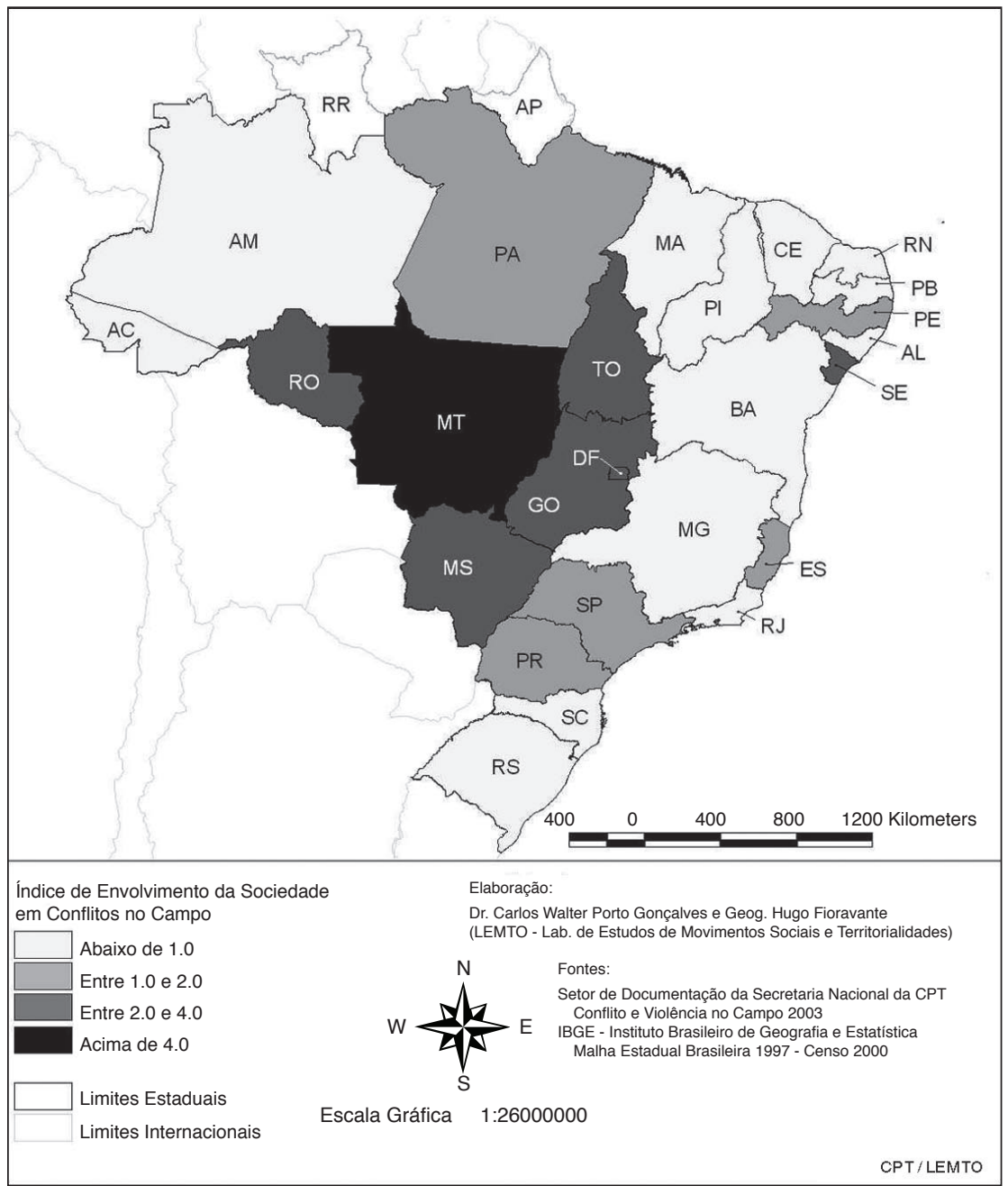


MAPA 4 - Índice de Intensidade da Ação do Poder Judiciário 1 - Pessoas Presas (2003)

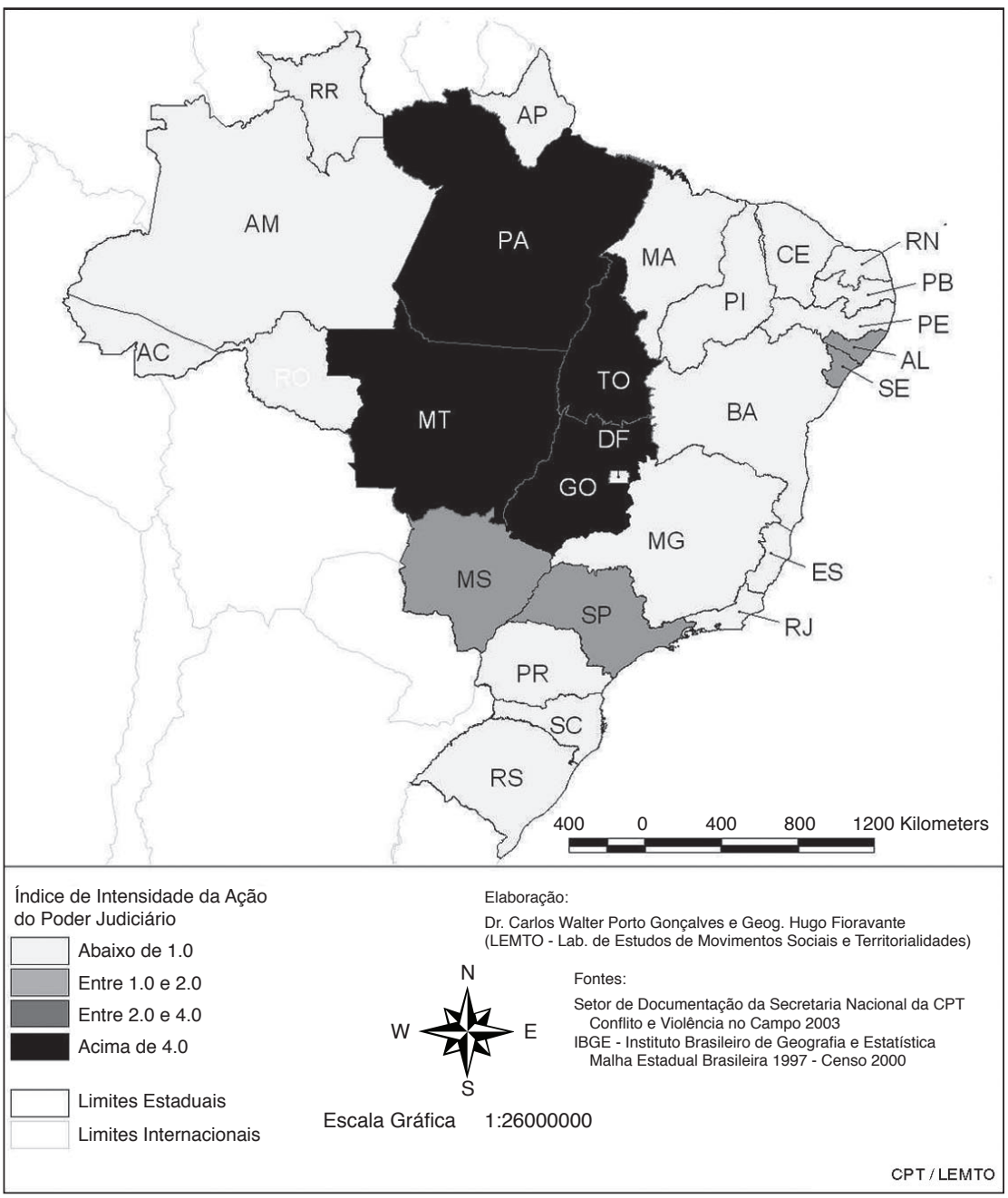




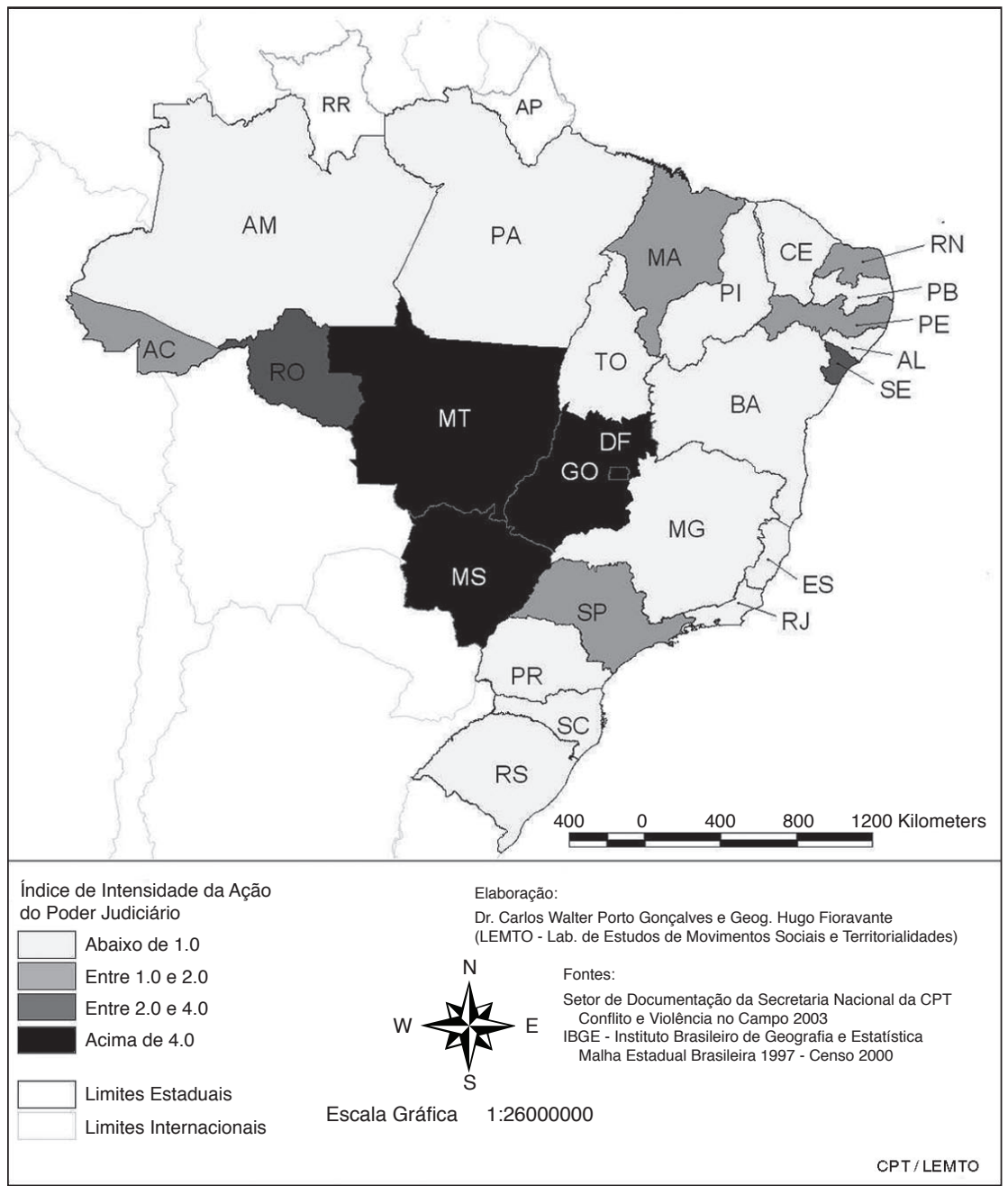




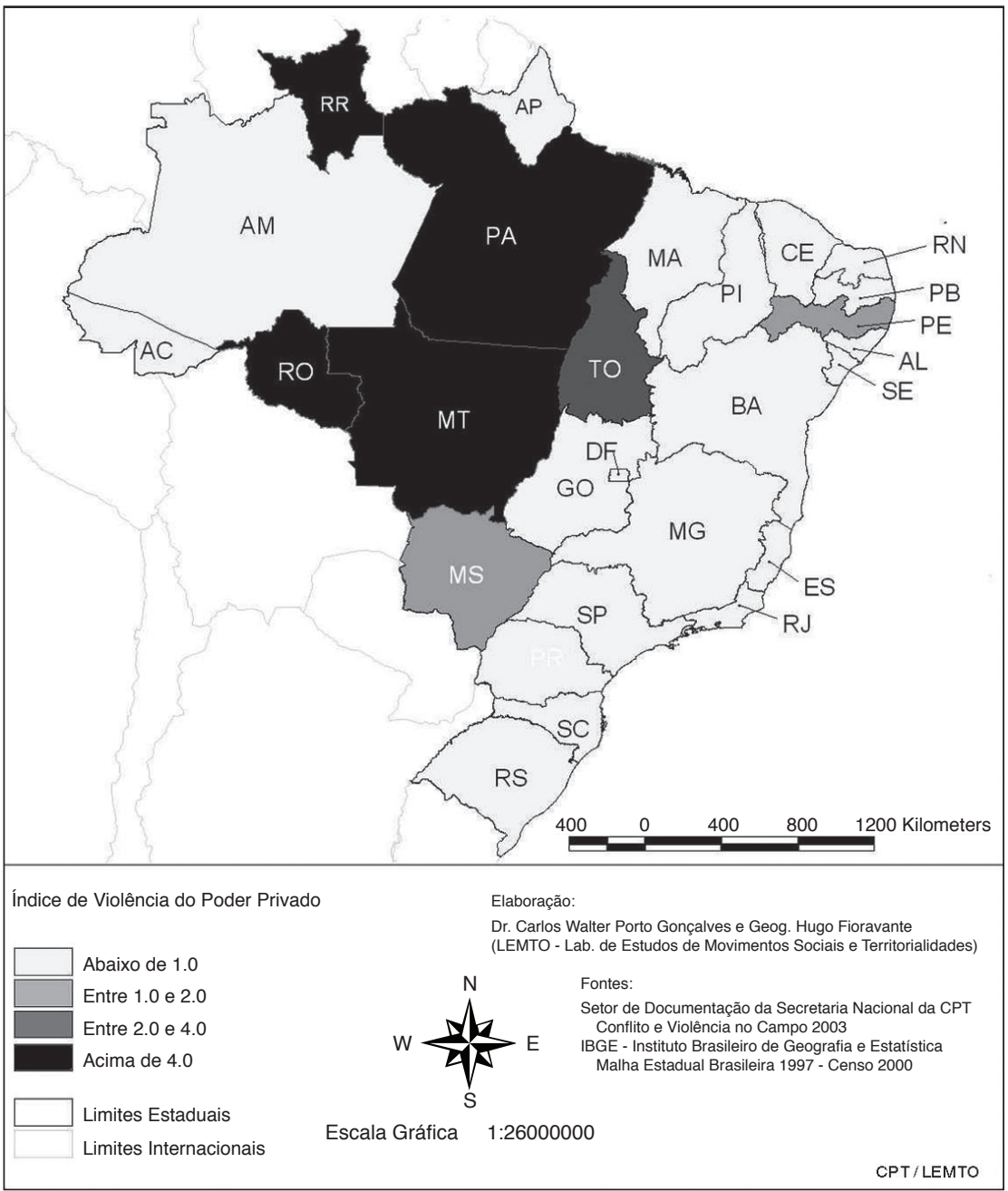


MAPA 7 - Índice de Violência do Poder Privado 2 - Famílias Expulsas (2003)

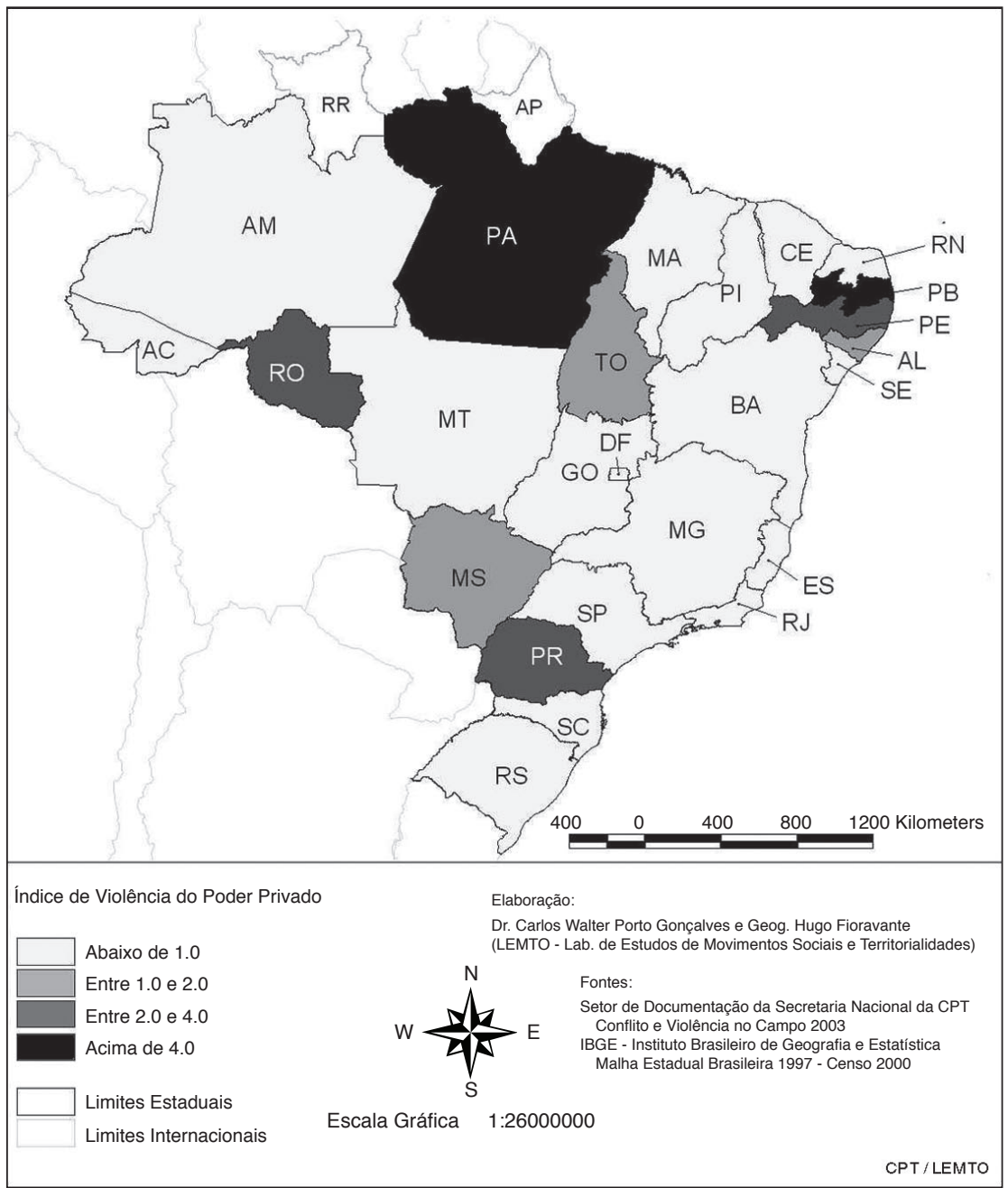

